Special Issue: Agricultural Productivity and Sustainability Improvement in Tropical Region

\title{
Phenotypic and Morphometric Characterization of Hycole, Hyla and New Zealand White Rabbits for KUAT Hybrid (Tropical Adaptive and Superior Rabbit)
}

\author{
Bram Brahmantiyo ${ }^{1, *}$, Henny Nuraini ${ }^{2,3}$, Astari Wibiayu Putri ${ }^{3},{\text { Maizirwan } \text { Mel }^{4,5} \text { and Cecep Hidayat }}^{6}$ \\ ${ }^{1}$ Indonesian Research Institute for Animal Production, West Java, Indonesia; ${ }^{2}$ Faculty of Animal Science, IPB University, \\ Bogor, West Java, Indonesia; ${ }^{3}$ Halal Science Center, IPB University, Bogor, West Java, Indonesia; ${ }^{4}$ Department of Biotechnology \\ Engineering, Faculty of Engineering, International Islamic University, Malaysia; ${ }^{5}$ The International Institute for Halal \\ Research and Training, International Islamic University, Malaysia; ${ }^{6}$ Indonesian Research Institute for Animal Production, \\ West Java, Indonesia.
}

Abstract | Hycole and Hyla rabbits were imported in 2012 and 2013. Hycole and Hyla rabbits were known as best broiler rabbit and had potentiality as genetic resources to develop Indonesian broiler rabbit. The aim of this study was to characterize phenotype of Hycole and Hyla rabbits to evaluate their adaptability in tropical environments. Research were held at Indonesian Research Institute for Animal Production, Ciawi, Bogor, Indonesia using 79 adult rabbits (20 does and 20 bucks of Hycole, 14 does and 12 bucks of Hyla, and five does and eight bucks of New Zealand white). The age of the rabbits evaluated in this experiment was rabbits with age 20 wk old. The mean birth weight for Hyla was $53.6 \mathrm{~g}+7.5 \mathrm{~g}$, Hycole was $51.6 \mathrm{~g}+9.9 \mathrm{~g}$, and NZW was $54.4 \mathrm{~g}+10.7 \mathrm{~g}$. This experiment was carried out for 3 mo. The feed used during the experiment was commercial feed. A complete randomized design with unbalanced data analysis was used for quantitative traits and descriptive analysis for qualitative traits. Qualitative characteristics of hair color variation of Hyla rabbit was different than other with $7.7 \%$ pointed on their white hair color, and hip type compact of Hycole, Hyla and New Zealand White were $90 \%, 84.6 \%$ and $76.9 \%$, respectively. Quantitative characteristics of chest depth of Hycole and Hyla rabbits were higher than New Zealand White. Hycole and Hyla rabbits showed high body size at Head height, Ear length, Ear width, Chest depth, Radius Ulna, Femoris, Length of the spine. Crossing of these rabbits with New Zealand White rabbit have potential to develop broiler rabbits that adapted in tropic.

Received | January 08, 2021; Accepted | February 03, 2021; Published | May 20, 2021

*Correspondence | Bram Brahmantiyo, Indonesian Research Institute for Animal Production, West Java, Indonesia; Email: brahmantiyo@gmail. com

Citation | Brahmantiyo, B., H. Nuraini, A.W. Putri, M. Mel and C. Hidayat. 2021. Phenotypic and morphometric characterization of hycole, hyla and New Zealand white rabbits for KUAT hybrid (tropical adaptive and superior rabbit). Sarbad Journal of Agriculture, 37(Special issue 1): 09-15. DOI | https://dx.doi.org/10.17582/journal.sja/2021/37.s1.09.15

Keywords | Breeding, Broiler rabbit, Hybrid crossing, Increase qualitative and quantitative, Oryctolagus cuniculus Linnaeus 1758.

\section{Introduction}

工ycole, Hyla rabbits were imported by the -Indonesian Research Institute for Animal Production (IRIAP) in 2012 and 2013, respectively.
Importations were done to overcome raising demand on broiler rabbit. Hycole, Hyla and New Zealand White rabbits have a superiority on high growth rate and prolification rate. The body weight of Hyla's rabbit in the age of $70 \mathrm{~d}$ can reach $2160 \mathrm{~g}$ (de la 
Fuente and Rosell, 2012), Hycole's rabbit can reach $2400 \mathrm{~g}$ to $2500 \mathrm{~g}$ (Brahmantiyo et al., 2017) and New Zealand White rabbit can reach $1998.30 \mathrm{~g}$ (Chodová et al., 2014). The three breeds of rabbit will be used in the program to develop a tropical adaptive superior rabbit [KUAT = kelinci unggul adaptif tropis (tropical adaptive and superior rabbit)].

Characterization of quantitative traits has been performed on Hycole, Hyla rabbits for litter size, growth rate, and morphometrics of the body (Setiaji et al., 2012). Crosses Hycole rabbit with NZW and their reciprocal has been done with the crossed Hycole sire and NZW dam $\left(\mathrm{P}_{\mathrm{A}} \mathrm{N}\right)$ (Brahmantiyo et al., 2017). The rabbit has potential to be developed as the genetic resources of dam adaptive to tropical climate due to its good heterosity (hybrid vigor) in litter size and growth rate (Khan et al., 2017a, 2017b; Tariq et al., 2015).

Besides, evaluating quantitative characteristhic, this study also evaluating qualitative characteristhic of Hycole, Hyla and New Zealand white rabbits in the context of developing KUAT. This study aimed to evaluate phenotypic and morphometric characterization of Hycole, Hyla and New Zealand white rabbits for KUAT hybrid.

\section{Materials and Methods}

The research was conducted at Rabbit Facility Unit, Indonesian Research Institute for Animal Production, Ciawi, Bogor, West Java. The materials used in the study include of Hycole (PP) rabbits of 14 does and 12 bucks, Hyla (CC) rabbits of 20 does and 20 bucks, and New Zealand White (NN) rabbits of five does and eight bucks. The age of the rabbits evaluated in this experiment was rabbits with age 20 wk (weeks) old. The mean birth weight for Hyla was $53.6 \mathrm{~g}+7.5 \mathrm{~g}$, Hycole was $51.6 \mathrm{~g}+9.9 \mathrm{~g}$, and NZW was $54.4 \mathrm{~g}+10.7 \mathrm{~g}$. This experiment was carried out for 3 mo (months). The feed used during the experiment was commercial feed with the nutritional content, i.e., $18 \%$ of crude protein, $4.0 \%$ of crude fat, $16 \%$ crude fiber, and $2500 \mathrm{Kcal} \mathrm{kg}^{-1}$ metabolic energy. The feed used was in the form of pellets.

Quantitative observation performed by measuring the morphometrics of each rabbit breed, ie. head (length, width, and height), chest (circumference, depth and width), length of front leg, rear leg, backbone, and ear, also the width of hip. Observation on qualitative properties include: (i) head type (oval elongate, oval, and rounded oval) was determined based on the index value of the width-size division to the head length was $<0.45$ then the head shape is oval elongated, the value of 0.45 to 0.50 oval head shape and $>0.50$ head shape is oval rounded; (ii) body type seen from the body shape while in a stationary, quiet position and the body of the rabbit is on a flat medium, there is a commercial body type, arc, semi-arc, compact and cylinder (Fig. 1; Hassan et al., 2012); (iii) eye color consisting of red and black; (iv) dominant body color is determined by looking at the colors that dominate the whole body of a rabbit; (v) hair color variations are categorized when the rabbit has only one hair color the same on the whole body then the rabbit has a single color variation. The rabbits with three or more mixtures of color on each hair shaft then the rabbit has an agouti color variation. The rabbit with variation of broken colors that rabbit has a combination of white hair color and other colors. The rabbit has a white hair color in most areas of the body and different hair color in the nose, ears, legs and tail then the rabbit has a variety of pointed white color. Variety of shaded colors were rabbits that has a darker hair color on the back, head, ears, tail and legs that graded the colors become lighter on the body. Rabbit wtih contrasting hair color on the eye circumference, nostrils, chest, abdomen, inner legs, lower tail, and inner edges of the ear then the rabbit has tan color variations, and rabbit has a protective hair color that is different from hair color on the skin surface then the rabbit has a variety of colors ticked (ARBA, 2011; Taha et al., 2017); (vi) Hair type is categorized when the rabbit has hair with a short size and a smooth texture then the rabbit has a normal hair type. Rex hair type expressed of short and straight hair on the skin and fine texture.
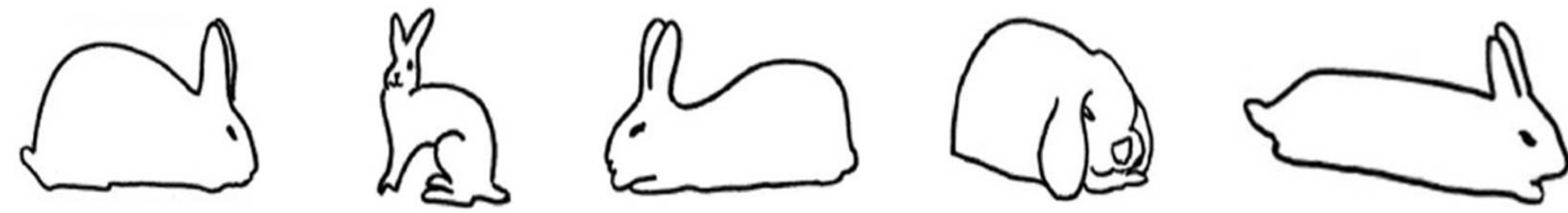

Figure 1: Commercial body type, arc, semi-arc, compact, and cylinder (ARBA, 2011). 

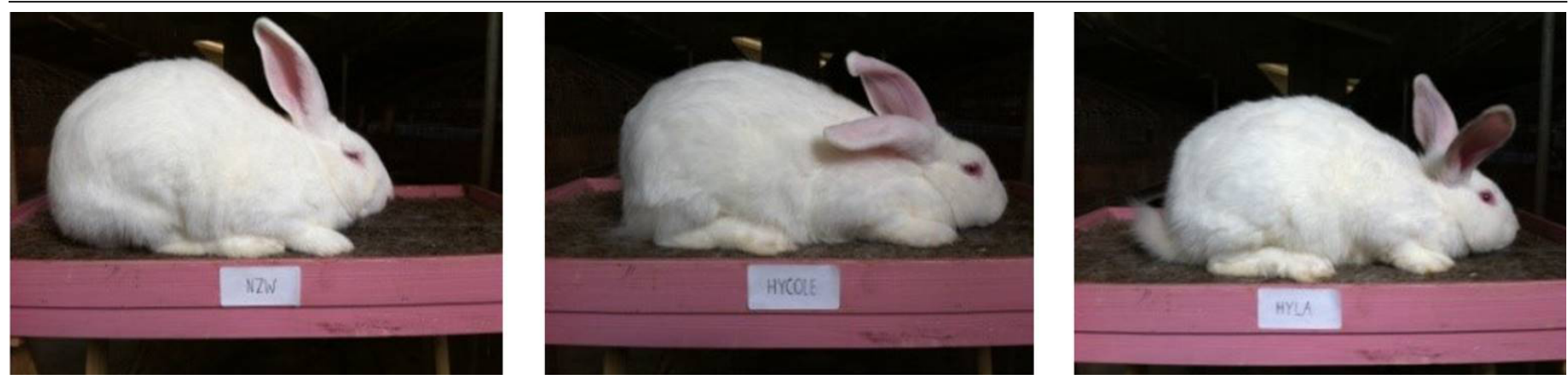

Figure 2: Hycole (PP), Hyla (CC) and New Zealand white (NN).

The rabbit has long hair, thin and smooth then the rabbit has angora hair type. Smaller diameter and the outer layer is transparent, shiny and slick then the rabbit has a satin hair type; (vii) Hip type is determined by palpation and see the shape of the hip surface from behind (Filho et al., 2012).

The complete randomized design factorial was applied for quantitative properties data (Jatoi et al. 2015), while the qualitative characteristic data is described descriptively based on the percentage.

\section{Results and Discussion}

\section{Qualitative characteristics}

Qualitative characteristics are individual traits that can be classified into groups based on apparent and definitely distinct traits for each group. Color variations, hair color patterns and eye color are qualitative traits influenced by color-coding genes, fur quality and softness are qualitative properties of commercial value (Mancini et al., 2017). Hycole, Hyla and New Zealand White rabbits shown at Figure 2.

The proportion of each qualitative traits of Hycole, Hyla and New Zealand White rabbits can be seen in Table 1. Qualitative characteristics are characteristics that can be seen only existence, not measured value or degree. There is a clear distinction between one characteristic with another characteristic and can not be made gradation (discontinuous).

According to their head index, PP, CC and NN had oval head type because they had the index value of the width-size division to the head length $>0.50$, and their body type are commercial (ARBA, 2011). Commercial body type of rabbits were expression of broiler rabbit that has a larger body size and shape (Abo-Eid et al., 2016). Eye color of three breeds of rabbit were red, that eye color is determined by the distribution and pigment content of melanocytes and melanosomes in the iris of eye. Covrig et al. (2013) reported that the red eyes that appear in white-haired rabbits are the expression of cc genes that cause albino on the surface of the body and red on the eyes. The absence of pigment on the skin, white-haired rabbits usually have red eyes (Covrig et al. 2013).

Table 1: Qualitative characteristics of Hycole (PP), Hyla $(C C)$, and New Zealand wbite (NN) rabbit.

\begin{tabular}{llccc} 
Traits & Phenotype & \multicolumn{3}{c}{ Rabbit breed (\%) } \\
& & PP & CC & NN \\
Head type & Oval & 100 & 100 & 100 \\
Body type & Commercial & 100 & 100 & 100 \\
Eyes color & Red & 100 & 100 & 100 \\
Dominan hair color & White & 100 & 100 & 100 \\
Hair color variation & Single & 100 & 92.3 & 100 \\
& Pointed white & - & 7.7 & - \\
Hair type & Normal & 100 & 100 & 100 \\
Hip type & Compact & 90 & 84.6 & 76.9 \\
& Slim & 10 & 15.4 & 23.1
\end{tabular}

There were four type of hair, normal, angora, rex and satin. PP, CC and NN rabbits have normal hair type because of short size and a smooth texture of hair. According to Neirurerová et al. (2019), normal hair type is owned by many strains of rabbits with various body sizes. Normal hair has a size of about $2.5 \mathrm{~cm}$ with a thin texture, smooth and compact. The most common hair color of rabbits is single hair color, agouti, broken, pionted white, shaded, tan, and ticked (Kabir, 2013). The dominant hair color of the three rabbit lines (PP, CC and $\mathrm{NN}$ ) is single and white. $\mathrm{CC}$ rabbit has a normal hair color variation of $92.3 \%$ and there are $7.7 \%$ have a variation of pointed white hair color. In addition to white, the dominant body color patterned rabbit pointed white can also be other colors (Kozioł et al., 2015). Variations of pointed white patterns on $\mathrm{CC}$ rabbits are black on the nose, ears, legs and tail. 
Table 2: Body size of rabbits based on breed and sex of rabbit.

\begin{tabular}{lcccccc} 
& \multicolumn{2}{c}{ Hycole (PP) } & \multicolumn{2}{c}{ Hyla (CC) } & \multicolumn{2}{c}{ New zealand white (NN) } \\
& Doe & Buck & Doe & Buck & Doe & Buck \\
Head length $(\mathrm{cm})$ & $12.98 \pm 0.64$ & $13.27 \pm 0.81$ & $13.16 \pm 0.42$ & $13.77 \pm 0.60$ & $12.86 \pm 0.69$ & $12.85 \pm 0.56$ \\
Head width $(\mathrm{cm})$ & $4.87 \pm 0.26$ & $5.30 \pm 0.42$ & $4.57 \pm 0.14$ & $5.15 \pm 0.37$ & $4.50 \pm 0.09$ & $5.11 \pm 0.25$ \\
Head height $(\mathrm{cm})$ & $6.34 \pm 0.39^{\mathrm{a}}$ & $5.30 \pm 0.42^{\mathrm{c}}$ & $5.93 \pm 0.38^{\mathrm{b}}$ & $6.34 \pm 0.40^{\mathrm{a}}$ & $6.14 \pm 0.32^{\mathrm{ab}}$ & $6.44 \pm 0.28^{\mathrm{a}}$ \\
Chest circumference $(\mathrm{cm})$ & $33.21 \pm 2.64$ & $31.88 \pm 2.26$ & $33.24 \pm 1.63$ & $33.21 \pm 1.85$ & $31.74 \pm 0.37$ & $32.78 \pm 1.24$ \\
Ear length $(\mathrm{cm})$ & $13.70 \pm 0.78^{\mathrm{ab}}$ & $13.77 \pm 0.76^{\mathrm{ab}}$ & $13.13 \pm 0.61^{\mathrm{b}}$ & $13.88 \pm 0.55^{\mathrm{a}}$ & $14.22 \pm 0.81^{\mathrm{a}}$ & $13.58 \pm 0.85^{\mathrm{ab}}$ \\
Ear width $(\mathrm{cm})$ & $8.42 \pm 0.62^{\mathrm{a}}$ & $8.30 \pm 0.55^{\mathrm{a}}$ & $8.37 \pm 0.44^{\mathrm{a}}$ & $7.90 \pm 0.51^{\mathrm{a}}$ & $7.28 \pm 0.46^{\mathrm{b}}$ & $8.05 \pm 0.48^{\mathrm{a}}$ \\
Chest depth $(\mathrm{cm})$ & $10.81 \pm 0.87^{\mathrm{a}}$ & $10.50 \pm 0.10^{\mathrm{a}}$ & $10.92 \pm 0.63^{\mathrm{a}}$ & $10.41 \pm 0.10^{\mathrm{a}}$ & $8.57 \pm 0.48^{\mathrm{b}}$ & $10.10 \pm 1.47^{\mathrm{a}}$ \\
Chest width $(\mathrm{cm})$ & $9.69 \pm 0.80$ & $9.32 \pm 0.94$ & $8.76 \pm 0.45$ & $8.95 \pm 0.73$ & $8.35 \pm 0.78$ & $8.50 \pm 0.65$ \\
Radius Ulna $(\mathrm{cm})$ & $10.83 \pm 0.54^{\mathrm{ab}}$ & $11.11 \pm 0.86^{\mathrm{a}}$ & $11.17 \pm 0.52^{\mathrm{a}}$ & $10.60 \pm 0.79^{\mathrm{ab}}$ & $10.30 \pm 0.40^{\mathrm{b}}$ & $10.71 \pm 0.49^{\mathrm{ab}}$ \\
Humerus $(\mathrm{cm})$ & $9.97 \pm 0.51$ & $9.95 \pm 0.82$ & $9.98 \pm 0.39$ & $10.16 \pm 0.65$ & $9.80 \pm 0.50$ & $10.00 \pm 0.19$ \\
Tibia $(\mathrm{cm})$ & $15.10 \pm 0.63$ & $15.11 \pm 0.61$ & $15.16 \pm 0.53$ & $15.58 \pm 0.46$ & $15.18 \pm 0.40$ & $15.04 \pm 0.41$ \\
Femoris $(\mathrm{cm})$ & $12.93 \pm 0.23^{\mathrm{a}}$ & $12.75 \pm 0.30^{\mathrm{a}}$ & $12.84 \pm 0.28^{\mathrm{a}}$ & $12.75 \pm 0.33^{\mathrm{a}}$ & $12.42 \pm 0.28^{\mathrm{b}}$ & $12.94 \pm 0.23^{\mathrm{a}}$ \\
Length of the spine $(\mathrm{cm})$ & $41.25 \pm 1.96^{\mathrm{a}}$ & $39.68 \pm 2.17^{\mathrm{ab}}$ & $38.51 \pm 2.17^{\mathrm{bc}}$ & $38.26 \pm 2.61^{\mathrm{bc}}$ & $37.26 \pm 1.48^{\mathrm{c}}$ & $39.15 \pm 1.12^{\mathrm{bc}}$ \\
Width of the spine $(\mathrm{cm})$ & $9.85 \pm 0.76$ & $9.78 \pm 1.00$ & $8.97 \pm 0.55$ & $9.34 \pm 0.56$ & $9.19 \pm 0.63$ & $9.12 \pm 0.80$
\end{tabular}

Different superscript letters on the same line, significantly different $(P<0.05)$.

Hip type of PP, CC and NN rabbits with compact hip type were $90 \%, 84.6 \%$, and $76.9 \%$, repectively and slim hip type were $10 \%, 15.4 \%$, dan $23.1 \%$, respectively. Rabbits that have a solid rounded hip shape show good muscle distribution (Asamoah et al., 2019; Bivolarski et al., 2011; Guo et al., 2016; Papadomichelakis et al., 2017; Suleman et al., 2020). According to ARBA (2011) the hip showed the condition of the rabbit's body. Rabbits that have a rounded or solid hip reflect that the rabbit also has a rounded and solid body. This suggests that the physical state of the rabbit is prime and has a good meat content.

\section{Quantitative characteristics}

Quantitative nature is the properties of production and reproduction or measurable properties, such as body weight and body size or morphological characteristics (Andronikov et al., 2019; Belabbas et al., 2019; Kadi et al., 2018; Petracci et al., 2018). Morphological characteristic is a structural form of organism that is the main source of characteristic of most organism groups. The size and shape of the body is a comprehensive predictor of the typical form and description of various body images that prove useful in analyzing many organism. Body weight that were expression of body size and body shape very important for breeding rabbits in commercial units (Fuente and Rosell, 2012). Hassan et al. (2012) reported that morphometric traits were highly correlated with body weight. Accordingly, the morphometric traits of rabbits can be used as a tool for selection in genetic improvement of rabbits, as well as to predict their body weight.

The three breed rabbits have similarities in head length, head width, chest circumference, chest width, humerus length, tibia length, femoris length, and hip width (Table 2). The interaction between breed and sex has a significant effect $(\mathrm{P}<0.05)$ on head height, length and width of the ear, chest depth, radius ulna length, and the length of the spine.

The chest circumference and the length of the spine reflect the productivity of the rabbit (Abdel-Kafy et al., 2018). The chest circumference of buck and doe rabbit's were $31.88 \mathrm{~cm} \pm 2.26 \mathrm{~cm}$ and $33.21 \mathrm{~cm} \pm 2.64$ $\mathrm{cm}$ of PP, $33.21 \mathrm{~cm} \pm 1.85 \mathrm{~cm}$ and $33.24 \mathrm{~cm} \pm 1.63$ $\mathrm{cm}$ of $\mathrm{CC}$, and $32.78 \mathrm{~cm} \pm 1.28 \mathrm{~cm}$ and $31.74 \mathrm{~cm} \pm$ $0.37 \mathrm{~cm}$ of NN, respectively. The length of the buck and doe rabbit's spine is as follows $39.68 \mathrm{~cm} \pm 2.17$ $\mathrm{cm}$ and $41.25 \mathrm{~cm} \pm 1.96 \mathrm{~cm}$ of PP, $38.20 \mathrm{~cm} \pm 2.61$ $\mathrm{cm}$ and $38.52 \mathrm{~cm} \pm 2.17 \mathrm{~cm}$ of CC, and $39.15 \mathrm{~cm} \pm$ $1.12 \mathrm{~cm}$ and $37.24 \mathrm{~cm} \pm 1.48 \mathrm{~cm}$ of $\mathrm{NN}$.

The size of chest circumference and the length of the spine of this study obtained $\mathrm{CC}$ rabbits have chest circumference $(32.21 \mathrm{~cm} \pm 1.85 \mathrm{~cm})$ and the length of spine of PP $(41.25 \mathrm{~cm} \pm 1.96 \mathrm{~cm})$ the highest and it's different from the results of Brahmantiyo et al. (2017) which obtained the highest chest circumference $(33.32 \mathrm{~cm})$ on the PP rabbit and the highest length of spine $(42.41 \mathrm{~cm})$ on the $\mathrm{NN}$ rabbit. This difference is influenced to several factors such as individual $2021 \mid$ Volume 37 | Special Issue 1 | Page 12 
differences measured, the process of adaptation to the environment, and the difference in rabbit generation measured. This study are agreement with Hassan et al. (2012) that said linear measurement or a combination of it can be used to predict live body weight or another linear trait and also can be use for genetic improvement.

Adaptation in the tropics, with ambient temperature and feeds avaibility, unplanned mating program were influence performance changes in the rabbit and may lead to inconsistent performance of its filial, which is very different from the performance of pure breed in the country of its origin. Imported rabbits that raised in Indonesia will adaptation to different climates resulting in changes in the rabbit body in both shape and performance when compared to their origin country (Cherwon et al., 2020; Pei et al., 2012; Sakr et al., 2019).

\section{Conclusions and Recommendations}

This study shows that the Hycole, Hyla and New Zealand White rabbits have body size that express their genetic potential in the tropics of Indonesia. Hycole and Hyla Rabbits have the potential genetics to develop broiler rabbits in Indonesia that can be crossed with New Zealand White rabbits. This crossbred were expected to produce adaptive tropical broiler rabbits with high productivity.

\section{Acknowledgment}

The authors wish thank to Head of Indonesian Research Institute for Animal Production as facilitator of this study.

\section{Novelty Statement}

Research related to broiler rabbits is still very rare in tropical countries, especially in Indonesia. This study shows novelty that phenotypic characteristics are very important to determine the adaptability and genetic expression of rabbits originated from subtropics that are kept in tropical climates for the development of rabbit breeding.

\section{Author's Contributions}

BB conceived and designed the study, and performed definition of intellectual content, literature search, experimental studies, data acquisition, data analysis, statistical analysis, manucripts preparation. $\mathrm{HN}$, AWP and $\mathrm{CH}$ elaborated the intellectual content, carried out literature search, experimental studies and manuscripts review. MM elaborated and carried out literature search, manuscripts editing, manuscripts review and guarantor.

\section{Conflict of interest}

The authors declares that there is no conflict of interests regarding the publication of this article

\section{References}

Abdel-Kafy, E.M., S.S. Ahmed, A. El-keredy, N.I. Ali, S. Ramadan and A. Farid. 2018. Genetic and phenotypic characterization of the native rabbits in Middle Egypt. Vet. World, 11: 1120-1126. https://doi.org/10.14202/ vetworld.2018.1120-1126

Abo-Eid, H.A., M.S. Abousekken and I.A.M. El-Folly. 2016. Rabbit growth performance as affected by dietary levels of date waste meal. Egyptian J. Nutr. Feeds, 19: 349-362. https:// doi.org/10.21608/ejnf.2016.74922

Andronikov, D., A. Kuzelov, J. Sazdova, K. Mojsov, A. Janevski, S. Jordeva and S.G. Longurova. 2019. Quantitative characteristics of rabbit hybrids. J. Agric. P1. Sci., 17: 9-14.

ARBA. 2011. Raising better rabbits and cavies. American Rabbit Breeders Association Inc., USA.

Asamoah, E.A., J. Barimah, W. Y. Akwetey, R. Boateng and C.C. Dapuliga. 2019. Sensory and physicochemical characteristics of rabbit meat sausages produced with refined palm stearin (RPS). J. Food Sci. Technol..,4: 796-803. https://doi.org/10.25177/JFST.4.5.RA.495

Belabbas, R., M. De la Luz García, H. Ainbaziz, N. Benali and A. Berbar. 2019. Growth performances, carcass traits, meat quality, and blood metabolic parameters in rabbits of local Algerian population and synthetic line. Vet. World, 12: 55-62. https://doi.org/10.14202/ vetworld.2019.55-62

Bivolarski, B.L., E.G. Vachkova , E.G. Vachkova and S.S. Ribarski. 2011. Effect of weaning age upon the slaughter and physicochemical traits effect of weaning age upon the slaughter and physicochemical traits of rabbit meat. Vet. Arch., 81: 499-511. 
Brahmantiyo, B., Y.C. Raharjo and L.H. Prasetyo. 2017. Production performance of HyCole, New Zealand White Rabbits and its reciprocal. Indonesian J. Anim. Vet. Sci., 22: 16-23. https:// doi.org/10.14334/jitv.v22i1.1590

Cherwon, A.K., M.M. Wanyoike and C.K. Gachuiri. 2020. Rabbit production practices in Kiambu County, Kenya. Int. J. Livest. Prod., 11: 114-121. https://doi.org/10.5897/ IJLP2020.0719

Chodová, D., E. Tumová, M. Martinec, Z. Bízková, V. Skřivanová , Z. Volek and L. Zita. 2014. Effect of housing system and genotype on rabbit meat quality. Czech J. Anim. Sci., 59: 190-199. https://doi.org/10.17221/7343-CJAS

Covrig, I., O.I. Gheorghe and T.C. Pătruțoiu. 2013. The C locus: Rabbit genetics for full color development, chinchilla, seal, sable, pointed black and red-eyed full white. Rabbit Genet., 3: 2332.

De la Fuente, L.F. and J.M. Rosell. 2012. Body weight and body condition of breeding rabbits in commercial units. J. Anim. Sci., 90: 32523258. https://doi.org/10.2527/jas.2011-4764

Filho, F.C.G., R. Guarniero, M.G. Júnior, C.A.M. Pereira, M.A. Matos and L.C. Garcia, 2012. Simple suture and anchor in rabbit hips. Acta Ortop. Bras., 20: 280-284. https://doi. org/10.1590/S1413-78522012000500007

Fuente, L. and J.M. Rosell. 2012. Body weight and body condition of breeding rabbits in commercial units. J. Anim. Sci., 90: 3252-3258. https://doi.org/10.2527/jas.2011-4764

Guo, R., Y.Wan, D.Xu, L.Cui,M. Deng, G.Zhang, R. Jia, W. Zhou, Z. Wang, K. Deng, M. Huang, F. Wang and Y. Zhang. 2016. Generation and evaluation of Myostatin knock-out rabbits and goats using CRISPR/Cas9 system. Scient. Rep., 6: 29855. https://doi.org/10.1038/srep29855

Hassan, H.E., K.M. Elamin, I.A. Yousif, A.M. Musa and M.A. Elkhairey. 2012. Evaluation of body weight and some morphometric traits at various ages in local rabbits of Sudan. J. Anim. Sci. Adv., 2: 407-415.

Jatoi, A.S., S. Mehmood, J. Hussain, H.M. Ishaq, Y. Abbas and M. Akram. 2015. Comparison of six-week growth performance in four different strains of Japanese quail (Coturnix coturnix japonica). Sarhad J. Agric., 31: 59-64 .

Kabir, M.A. 2013. Breeding and coat-colour of rabbits. US Open Livest. Prod. J., 1: 1-7.
Kadi, S.A., M. Ouendi, C. Bannelier, M. Berchiche and T. Gidenne. 2018. Nutritive value of sundried common reed (Phragmites australis) leaves and its effect on performance and carcass characteristics of the growing rabbit. World Rabbit Sci., 26: 113-121. https://doi. org/10.4995/wrs.2018.5217

Khan, K., S. Khan, N. Khan and N. Ahmad. 2017a. Production performance of indigenous rabbits under traditional and intensive production systems in Northern Pakistan. J. Anim. Pl. Sci., 27: 75-81.

Khan, S., M.H. Khan, S. Muhammad, K. Kaleem and P. Shah. 2017b. Phenotypic and morphometric characteristics of Angora rabbits in rabbit model farm Jabba Mansehra. Khyber Pakhtunkhwa-Pakistan. J. Biol. Agric. Healthc., 7: 68-71. https://doi.org/10.12980/ apjtd.7.2017D7-2

Koziol, K., D. Maj and J. Bieniek. 2015. Changes in the color and $\mathrm{pH}$ of rabbit meat in the aging process. Med. Weter, 71: 104-108.

Mancini, S., G. Preziuso, F. Fratini, B. Torracca, R. Nuvoloni, A. Dal bosco and G. Paci. 2017. Qualitative improvement of rabbit burgers using Zingiber officinale Roscoe. powder. World Rabbit Sci., 25: 367-375. https://doi. org/10.4995/wrs.2017.7656

Neirurerová, P., M. Fik, J. Andreji and E. Mamojková. 2019. Analysis of coat quality of Chinchilla rabbit breed. Acta Fytotech. Zootech., 22: 17-20. https://doi.org/10.15414/ afz.2019.22.01.17-20

Papadomichelakis, G., E. Zoidis, A. Pappas and I. Hadjigeorgiou. 2017. Seasonal variations in the fatty acid composition of Greek wild rabbit meat. Meat Sci., 134: 158-162. https://doi. org/10.1016/j.meatsci.2017.08.001

Pei, Y., Y. Wu, J. Cao and Y. Qin. 2012. Effects of chronic heat stress on the reproductive capacity of male Rex rabbits. Livest. Sci., 146: 13-21. https://doi.org/10.1016/j.livsci.2012.02.015

Petracci, M., F. Soglia and F. Leroy. 2018. Rabbit meat in need of a hattrick: from tradition to innovation (and back). Meat Sci., 146: 93-100. https://doi.org/10.1016/j.meatsci.2018.08.003

Sakr, O.G., B.H. Mousa, K.R.S. Emam, A.S. Morsy and N. A.E. Ahmed. 2019. Effect of early heat shock exposure on physiological responses and reproduction of rabbits under hot desert conditions. World Vet.J., 9: 90-101. https://doi. 
org/10.36380/scil.2019.wvj13

Setiaji, A., E. Sutopo and Kurnianto. 2012. Morphometric characterization and genetic distance among four breeds of Rabbit (Oryctolagus cuniculus). Anim. Prod., 14: 92-98.

Suleman, S., S.A. Khan and M.H. Aziz. 2020. Effect of breed on growth performance and carcass quality attributes of apparently healthy male weanling rabbits under a conventional housing system. Turk. J. Vet. Anim. Sci., 44:
945-949. https://doi.org/10.3906/vet-1912-61

Taha, E.A., A.H. Samia and A.I. Nasr. 2017. Evaluating skin quality of some rabbit breeds under Egyptian conditions. World Rabbit Sci., 25: 193-200. https://doi.org/10.4995/ wrs.2017.6652

Tariq, M.R., M.I. Khan, A. Sameen and M. Nisa. 2015. Enrichment of flaxseed for developing functional rabbit meat. Sarhad J. Agric., 31: 7074. 